\title{
KNOWLEDGE, ATTITUDE AND PRACTICE ON MENTAL HEALTH AMONG HEALTH WORIERS SERVING A BLOCK OF A DISTRICT OF WESTERN INDIA.
}

KEY WORDS:Health Workers, Knowledge, Attitude and Practice, Mental Health, Rural Population

\section{Dr. Shobha Misra*}

\section{Dr. Mehul Patel}

\section{Dr. Rajat Oswal}

Professor \& Head, Department of Community Medicine, PDU Govt. Medical College Rajkot, Gujarat, India-36000 . *Corresponding Author

Assistant Professor, Department of Community Medicine, Pacific Institute of Medical Sciences, Udaipur, Rajasthan, India. Vadodara, Gujarat, India.

Background: Mental health services can be provided efficiently by primary health care workers with communitybased initiatives and task-sharing strategies. The study was carried out to assess the knowledge, attitude and practice regarding mental health among health workers serving a block of a district ofWestern India. Methods: A cross sectional study was conducted among 47 health workers serving rural and tribal population of a block of a district ofWestern India. Accredited Social Health Activists, Auxiliary Nurse Midwives, Field level workers; one each from the selected 12 villages were interviewed through a semi structured Questionnaire.

Results: The 50th percentile knowledge and attitude-practice among health care workers was $63.46 \%$ and $72.78 \%$ respectively. Overall mean knowledge was $64.12 \%$. There was no gender difference in the scores. Faith healing/quack (bhuva, bhagat) was options for treatment as mentioned by four-fifth of them and dargah/temple by two-third of them. All of them were aware of medicines as options for treatment and nearly $60 \%$ mentioned conversations and electric shock as options too.

Conclusions/Recommendations: There is a need of a tailored made intervention developed in collaboration with psychiatrist and public health expert on mental health to empower primary health care workers.

\section{INTRODUCTION:}

People with serious mental health problems die prematurely because of preventable physical conditions, as early as two decades ${ }^{(1)}$. It is estimated that $l$ in every 4 families has a member suffering from a mental health disorder ${ }^{(2)}$. The potential lack of equal involvement in family life, normal social networks and sustainable jobs, as well as decreased chances of rehabilitation, may be impeded by their ability to access care and may influence the form of treatment and quality of help obtained ${ }^{(3)}$. The WHO has given evidencebased intervention models, called the Mental Health Gap Action Program (mhGAP) intervention guide, to help integration with primary health care ${ }^{(4)}$. Changing the role of specialist mental health staff (i.e. psychiatrists and psychologists) from a primary emphasis on service delivery to also developing and building clinical capacity of the primary health care ( PHC) staff and providing oversight and quality assurance of mental health services, could aid in scaling up mental health services in the Low and Middle Income Countries (LMIC) ${ }^{(5-7)}$.

In the Indian community scenario, it is observed that there are a lot of stigmatizations which are responsible for huge healthcare burden as it takes time, expensive investigations due to the general practitioners' insensitivity to depression and stigmatization and hence significant healthcare time is wasted. And by the time the patient reaches the consultant, he/she is either in a severe state of illness or reached a poor prognosis of the illness. Mental health services can be provided efficiently by primary health care workers with community-based initiatives and task-sharing strategies. This would lead to decrease in morbidity arising out of these illnesses. The present study was therefore carried out to assess the knowledge, attitude and practice (KAP) regarding mental health among health workers serving a block of a district of Western India.

\section{METHODS:}

A cross sectional study was conducted among health workers serving rural and tribal population of a block of a district of Western India in 2015. This block covered approximately 120 villages and comprised of 3000 households (Hhs).

\section{Sampling Framework/Technique:}

Based on feasibility sampling at stage one: One sub-center from each of the six Primary Health Centre (PHC) of the block of the district was selected for study by simple random sampling method. A sub-center wise list of villages of the six sub-centers selected was then obtained. At stage two: two villages from each of the sub-centers were selected, also by simple random sampling method. Therefore, in this way a total of 12 villages were selected. At stage three:12 Accredited Social Health Activists (ASHA), 12 Auxiliary Nurse Midwives (ANM), 12 Field level workers; one each from the selected villages were decided to be studied.

\section{Data Collection:}

One day training session for research Assistants, Post Graduate Students was conducted for carrying out data collection. The study participants were interviewed through a semi structured questionnaire which was pilot tested. Informed verbal consent was obtained and confidentiality was maintained. The data was entered in STATA software and the statistical tests applied were Chi-squared test, " $t$ " test and ANNOV apart from descriptive statistics.

\section{RESULTS:}

A total of 47 health workers were interviewed to assess their KAP regarding mental health (on an average 8 from each of the six PHCs). They included; 14 Panchayat Members/ Sarpanch, 12 ASHAs, 12 ANMs, 4 mental health link workers, 2 Anganwadi Workers, 2 Multipurpose Health workers and 1 Anganwadi Helper.

There were $34 \%$ of health workers in the age group of $21-30$ years followed by those in the age group of 41-50 years $(31.9 \%)$. The mean age (mean+- SD) was $39.09+/-11.723$, respectively. Majority of them were females (76.6\%). Almost all of them (93.6\%) (Except 3) were Hindus. Almost half of them $(46.8 \%)$ were educated up to secondary school followed by $27.7 \%$ who were educated up to higher secondary. More than half of them $(57.4 \%)$ had not received any kind of training. 
Table 1: Percentile distribution related to Knowledge, Attitude and Practice of the Health Workers studied

\begin{tabular}{|l|l|l|}
\hline Percentiles & $\begin{array}{l}\text { Knowledge } \\
\text { Percentage (N=52)* }\end{array}$ & $\begin{array}{l}\text { Attitude and Practice } \\
\text { Percentage }(\mathbf{N}=1 \mathbf{1}) *\end{array}$ \\
\hline 25 & 57.69 & 54.55 \\
\hline 50 & 63.46 & 72.78 \\
\hline 75 & 76.92 & 81.82 \\
\hline
\end{tabular}

* Items in the Knowledge and Attitude \& Practice questionnaire

The 50th percentile, knowledge and attitude-practice among community members was $63.46 \%$ and $72.78 \%$ respectively as shown in Table 1.

Table 2: Knowledge of Health Workers regarding Mental Health and Illnesses

\begin{tabular}{|l|l|l|}
\hline Knowledge items & $\begin{array}{l}\text { Mean Score (correct } \\
\text { Knowledge) }\end{array}$ & $\begin{array}{l}\text { Std. } \\
\text { Deviation }\end{array}$ \\
\hline $\begin{array}{l}\text { General Mental } \\
\text { Disease(N=6) }\end{array}$ & 3.27 & 1.579 \\
\hline $\begin{array}{l}\text { Factor Affecting Mental } \\
\text { Diseases (N=10) }\end{array}$ & 5.68 & 1.249 \\
\hline Insights(N=8) & 4.95 & 1.133 \\
\hline $\begin{array}{l}\text { Sign and } \\
\text { symptoms(N=23) }\end{array}$ & 17.05 & 3.525 \\
\hline Treatment(N=5) & 3.73 & 0.935 \\
\hline $\begin{array}{l}\text { Overall } \\
\text { Knowledge(N=52) }\end{array}$ & 35.09 & 5.588 \\
\hline
\end{tabular}

The overall Knowledge of health workers regarding various aspects of mental health and illness was $35.09 / 52(67.4 \%)$. It is also noted that the score is half or little more than half for each of the knowledge items, Table 2 .

Table 3: Gender, Age and Education-Wise comparison of Knowledge, Attitude and Practice regarding Mental Health and Illness in HealthWorkers

\begin{tabular}{|c|c|c|c|c|c|c|}
\hline \multicolumn{3}{|l|}{ Variable } & \multirow[t]{2}{*}{$\mathbf{N}$} & \multirow{2}{*}{\begin{tabular}{|l|l|}
$\begin{array}{l}\text { Mean } \\
\%\end{array}$ \\
64.86 \\
\end{tabular}} & \multirow{2}{*}{\begin{tabular}{|l}
$\begin{array}{l}\text { Std. } \\
\text { Deviation }\end{array}$ \\
11.79
\end{tabular}} & \multirow{2}{*}{\begin{tabular}{|l} 
p-value \\
0.829 \\
\end{tabular}} \\
\hline \multirow{11}{*}{$\begin{array}{l}\text { Knowle } \\
\text { dge } \\
\text { Percent } \\
\text { age } \\
(\mathrm{N}=52)\end{array}$} & \multirow[t]{2}{*}{ Gender } & Male & & & & \\
\hline & & Female & 36 & 63.88 & 13.29 & \\
\hline & \multirow[t]{4}{*}{ Age } & $21-30$ & 16 & 66.26 & 11.43 & \multirow{4}{*}{$\begin{array}{l}\text { One way } \\
\text { ANOVA } \\
F=0.654, \\
d f=3, \\
p=0.585\end{array}$} \\
\hline & & $31-40$ & 8 & 60.09 & 19.00 & \\
\hline & & 41-50 & 15 & 62.31 & 11.11 & \\
\hline & & $>50$ & 8 & 67.31 & 12.16 & \\
\hline & \multirow[t]{5}{*}{ Education } & Graduate & 4 & 68.75 & 8.65 & \multirow{5}{*}{$\begin{array}{l}\text { One way } \\
\text { ANOVA } \\
\text { F } 1.361, \\
p=0.264\end{array}$} \\
\hline & & HSC & 13 & 63.31 & 10.55 & \\
\hline & & SSC & 22 & 63.64 & 13.38 & \\
\hline & & \begin{tabular}{|l|} 
Primary \\
\end{tabular} & 7 & 68.13 & 15.26 & \\
\hline & & Illiterate & 1 & 38.46 & - & \\
\hline \multirow{11}{*}{$\begin{array}{l}\text { Attitude } \\
\& \\
\text { Practice } \\
\text { Percent } \\
\text { age }\end{array}$} & \multirow{2}{*}{ Gender } & Male & 11 & 76.85 & 15.93 & \multirow[t]{2}{*}{0.092} \\
\hline & & Female & 36 & 64.89 & 21.19 & \\
\hline & \multirow{4}{*}{ Age } & $21-30$ & 16 & $65.91 \%$ & 20.59 & \multirow{4}{*}{$\begin{array}{l}\text { One way } \\
\text { ANOVA } \\
F=3.745, \\
d f=3 \\
p=0.018\end{array}$} \\
\hline & & $31-40$ & 8 & 55.68 & 21.42 & \\
\hline & & 41-50 & 15 & 66.06 & 18.97 & \\
\hline & & $>50$ & 8 & 86.36 & 10.87 & \\
\hline & \multirow[t]{5}{*}{ Education } & Graduate & 4 & 61.36 & 23.91 & \multirow{5}{*}{$\begin{array}{l}\text { One way } \\
\text { ANOVA } \\
F=0.465, \\
p=0.761\end{array}$} \\
\hline & & \begin{tabular}{|l|}
$\mathrm{HSC}$ \\
\end{tabular} & 13 & 69.23 & 17.22 & \\
\hline & & SSC & 22 & 66.12 & 23.50 & \\
\hline & & Primary & \begin{tabular}{|l|}
7 \\
\end{tabular} & 70.13 & 17.18 & \\
\hline & & Illiterate & 1 & 90.91 & - & \\
\hline
\end{tabular}

Table 3, shows that the knowledge or attitude and practice was not significantly different in both the genders $(p=0.829$ and $p=0.092$ respectively). The mean percentage of knowledge was maximum in the age group of more than 50 years $(67.31 \%)$. Likewise, mean percentage of attitude and practice was maximum in the age group of more than 50 years $(86.36 \%)$. The mean knowledge difference in the age groups was not significant $(p=0.585)$, however, the mean attitude and practice difference between the different age groups was significant $(p=0.018)$. ANOVA test results did not show any difference in knowledge or attitude-practice as per their educational status ( $p=0.264$ and $p=0.761)$ respectively.

Nomenclature of general mental diseases as mentioned by health workers included; psychosis (63.8\%), anxiety (61.7\%), depression (53.2\%), substance abuse (Alcohol / Tobacco / Ganja) (42.6\%), sleep disorders (38.3\%) and dementia (34\%). Drugs or alcohol (85.1\%), black magic or witch-craft $(74.5 \%)$, traumatic events or shock $(74.5 \%)$, possession by evil spirit $(68.1 \%)$, God's punishment \& brain disease $(63.8 \%)$, genetic or familial $(61.7 \%)$ and poverty $(27.7 \%)$ were the causes responsible for the mental health problem according to respondents. Signs and Symptoms; Irritability, aggression, violence, frequently having same thoughts, repeating same activities, anxiety, self-talk, sadness hopelessness were mentioned by four-fifth of them. Aloofness, not taking self-care, suicidal thoughts, having doubts, tobacco, hallucinations, sleep problems, alcohol were known to two-third of them. Excessive joy, development delays / speech problem, headache $\&$ body ache, weakness and disturbances in sexual activity were mentioned by nearly half of them.

Participants opined that mental health problems are treatable $(93.6 \%)$, old age people can have mental health problems $(87.2 \%)$, mental health problems are worthy of serious concern and attention (76.6\%), people of all ages can have mental health problem $(68.1 \%)$, children can have mental health problems $(68.1 \%)$, people with mental illness can work in a regular job (34\%) and mentally ill patient can be treated outside the hospital (29.3\%). All mentally ill patients were a nuisance to the public (23.4\%) was mentioned by one-fourth of them. Faith healing/quack (bhuva, Bhagat) was options for treatment as mentioned by four-fifth of them and dargah/temple by two-third of them. All of them were aware of medicines as options for treatment and nearly $60 \%$ mentioned conversations and electric shock as options too.

\section{DISCUSSION:}

In the current study it was found that fair number of health workers was aware about nomenclature of general mental diseases which included psychosis (63.8\%), anxiety (61.7\%), depression $(53.2 \%)$ and others. In similar studies, mental health awareness has been found in the range of $33.4 \%$ to $78.3 \%$ among health care providers ${ }^{(8-10)}$. Distribution of causes responsible for the mental health problems according to respondents in the present study were in line with studies conducted by Almanzar S et al and Jugal $\mathrm{K}$ et al ${ }^{(11-12)}$.

In the current study participants opined that mental health problems are treatable (93.6\%), old age people can have mental health problems $(87.2 \%)$ and people with mental illness can work in a regular job (34\%). Similar findings are cited by Gartoulla P et al among health professionals of Nepal, they found that most of the respondents (98\%) thought that mental illnesses have effective treatment and about $38 \%$ of the respondents opined that mentally ill patients should not be allowed to be engaged in work or job ${ }^{(13)}$. Kapungwe et al also cited that $39 \%$ of respondents agreed or strongly agreed that mentally ill people should be allowed to work ${ }^{(10)}$.

In a study by DM Ndetei et al, $68.6 \%$ of nurses felt that mental illnesses can be successfully managed in general hospitals and at outpatient facilities ${ }^{(14)}$. A study by Kishore Jugal et al found that $92 \%$ of the respondents considered mental illness to be treatable ${ }^{(12)}$. Aruna $\mathrm{G}$ et al found that majority of the students $(73 \%)$ held the view that psychiatric disorders are treatable ${ }^{(15)}$.While N Blaise et al cited that $39.5 \%$ mentioned so (9).

Faith healing/quack (bhuva, Bhagat) was options for treatment as mentioned by four-fifth of them and dargah/temple by two-third of them. Joshua Cowan et al 
among doctors of Bangalore found that there was a commonly held belief that medications produce a satisfactory result for patients with mental health problems ${ }^{(8)}$.A study by Aruna $\mathrm{G}$ et al cited that $80.4 \%$ thought of psychotherapy as an essential part of treatment, faith-healers (63.1\%) and electroconvulsive therapy (ECT) $(72 \%)^{(15)}$.

\section{Recommendations:}

There is a need of a tailored made intervention developed in collaboration with psychiatrist and public health expert on mental health to empower Link workers, Medical Social Psychiatrist and Accredited Social Health Activist (ASHA) regarding knowledge of signs and symptoms of mental illness and other aspects as identified by the study. The program should have strong component of reviewing the social causes of disease, stigmas/myths, health seeking behavior that delays disease diagnosis and treatment. The correct referral pathway for diagnosis and treatment of mental illnesses should be informed.

\section{Acknowledgement:}

The Authors acknowledge and are thankful to; the respondents who had truly given their views and participated openly; faculty and post-graduate students for data collection and support as and when required.

\section{REFERENCES:}

1. Mental health [Internet]. [cited 2020 Sep 24]. Available from: https:// www. who.int/westernpacific/health-topics/mental-health

2. Weltgesundheitsorganisation - 2002 - Mental health new understanding, new hope.pdf [Internet]. [cited 2020 Sep 24] . Available from: https://www. who.int /whr/2001/en/whr01_en.pdf?ua=1

3. Weltgesundheitsorganisation, editor. Mental health:new understanding, new hope.repr. Geneva:World Health Organization;2002.178 p. (The world health report).

4. mhGAP Intervention Guide - Version 2.0 [Internet]. [cited 2020 Sep 29]. Available from: https://www.who.int/publications-detail-redirect/mhgapintervention-guide---version-2.0

5. Ginneken N van, Tharyan P, Lewin S, Rao GN, Meera SM, Pian J, et al. Non-specialist health worker interventions for the care of mental, neurological and substance-abuse disorders in low and middleincome countries. Cochrane Database Syst Rev [Internet]. 2013 [cited $2020 \mathrm{Sep}$ 29];(11). Available from: https://www.readcube.com/ articles $/ 10.1002 \%$ 2F14651858.CD009149.pub2

6. Eaton J,McCay L, Semrau M, Chatterjee S, Baingana F, Araya R, et al. Scale up of services for mental health in low-income and middle-income countries. The Lancet. 2011 Oct;378(9802):1592-603.

7. Patel V, Weiss HA, Chowdhary N, Naik S, Pednekar S, Chatterjee S, et al. The effectiveness of a lay health worker led intervention for depressive and anxiety disorders in primary care: the MANAS cluster randomized trial in Goa, India. Lancet Lond Engl.2010 Dec 18;376(9758):2086-95.

8. Cowan J, Raja S, Naik A, Armstrong G, Prince M, Patel V, et al. Knowledge and attitudes of doctors regarding the provision of mental health care in Doddaballapur Taluk, Bangalore Rural district, Karnataka. Int J Ment Health Syst. 2012;6(1):21.

9. Blaise N-YH. Knowledge and Social Distance Towards Mental Disorders in an Inner-City Population: Case of University Students in Cameroon. Trends Med Res.2015 Apr 1;10(4):87-96.

10. Kapungwe A, Cooper S, Mayeya J, Mwanza J, Mwape L, Sikwese A, et al. Attitudes of primary health care providers towards people with mental illness: evidence from two districts in Zambia. Afr J Psychiatry. 2011;14 (4):290-7.

11. Almanzar S, Shah N,Vithalani S, Shah S, Squires J, Appasani R, et al. Knowledge of and attitudes toward clinical depression among health providers in Gujarat, India. Ann Glob Health. 2001;80(2):89-95.

12. Jugal K, Mukherjee R, Parashar M, Jiloha R, Ingle G. Beliefs and attitudes towards mental health among medical professionals in Delhi. Indian J Community Med.2007;32(3):198.

13. Gartoulla P, S P, Pandey R. Knowledge Status on Mental Health among Health Professionals of Chitwan District,Nepal.J Inst Med. 2015;37.

14. Ndetei D, Khasakhala L, Mutiso V, Mbwayo A. Knowledge, attitude and practice (KAP) of mental illness among staff in general medical facilities in Kenya: practice and policy implications. Afr J Psychiatry. 2011;14(3):225-35.

15. Aruna G, Mittal S, Yadiyal MB, Acharya C, Acharya S, Uppulari C. Perception, knowledge, and attitude toward mental disorders and psychiatry among medical undergraduates in Karnataka: A cross-sectional study. Indian J Psychiatry.2016;58(1):70-6. 